\title{
High-Cycle Fatigue of Austempered Ductile Irons in Various-Sized Y-Block Castings
}

\author{
Chih-Kuang Lin and Jing-Yuan Wei \\ Department of Mechanical Engineering, National Central University, \\ Chung-Li, Taiwan 32054, Republic of China
}

\begin{abstract}
High-cycle fatigue (HCF) properties of a number of different grades of austempered ductile irons (ADIs) were investigated. Ductile irons were prepared as Y-block castings with three section sizes (25, 50, and $100 \mathrm{~mm}$ in thickness). Fatigue specimens were selected from various locations within the castings, austenitized at $1173 \mathrm{~K}$, and then austempered at 573 and $633 \mathrm{~K}$, respectively. HCF tests were conducted by rotary bending method to generate the S-N curves and the associated fatigue limits. As section size increased, the HCF strength of ADI was decreased and affected by the inferior graphite nodule morphology and microshrinkage porosity resulting from the slower solidification rate. The effects of section size, location within the heavy-section casting, and austempering temperatures on the HCF strength of ADI are interpreted in terms of the graphite nodule morphology and microshrinkage pores. An empirical equation was introduced to correlate the fatigue limit of ADI with the impact toughness value and mean nodule diameter.
\end{abstract}

(Received September 1, 1996)

Keywords: austempered ductile iron, high-cycle fatigue, cast section size, graphite nodule morphology, microshrinkage pores, impact toughness

\section{Introduction}

Recently, there has been an increasing demand for the introduction of austempered ductile iron (ADI) as a new engineering material because the material has a good combination of high strength, ductility, toughness, fatigue strength, and wear resistance over other ductile irons ${ }^{(1)-(3)}$. In particular, $\mathrm{ADI}$ is an attractive, economical substitute for forged steels and cast steels as automobile components such as gears, crankshafts, connecting rods and others ${ }^{(1)}$. These applications involve using ADI castings of various section sizes. It is well known that mechanical properties of ductile irons usually deteriorate as cast section size increases ${ }^{(4)}$ and this is true for ADI as well ${ }^{(5)(6)}$. Nodule counts and nodularity decrease as section size increases, resulting from a slower solidification rate. In addition, casting defects associated with the last to freeze volumes such as microshrinkage porosity, slag entrapment, and segregation of alloy elements are also responsible for the degradation of mechanical properties in heavier sections $s^{(4)}$.

It is expected that fatigue properties of cast irons would also be affected by section size. In fact, some of the previous work on ductile irons has demonstrated that fatigue strength was consistently decreased with increasing section size for various casting geometries ${ }^{(7)(8)}$. This was attributed to a combination of several microstructural factors, including increasing effects of nodule morphology and alloy segregation in the heavier-section castings. As ADI is a newly developed material, very few data are available on the section size dependence of fatigue properties in this material. Mayer and Barbezat ${ }^{(9)}$ reported that the rotary bending fatigue strength of a Sulzer GGG-
100 ADI was reduced by $\sim 15 \%$ as the wall thickness increased from 40 to $200 \mathrm{~mm}$. They blamed this reduction in fatigue strength on the increase of nodule and microdefect size. Tanaka et al. ${ }^{(10)}$ attributed the decrease in fatigue limits of some ADIs to the increase in nodule diameter with increasing section size by conducting reversed plane bending fatigue tests on specimens cut from Y-blocks with various thicknesses ranging from 11 to $60 \mathrm{~mm}$. An interesting result reported by Faubert et $a l .{ }^{(11)}$ indicated that the position in the casting did not significantly influence the fatigue limit of a heavysection ADI.

The great interest in using ADI in many applications requires a more comprehensive data base on the mechanical and fatigue properties of different ADIs with various section sizes. The published data regarding the effect of cast section size on ADI fatigue properties are still limited, thus providing a need for experimental work to be completed. The present study is intended to increase the data base and understanding of ADI's fatigue properties so as to better predict the fatigue life of ADI components in service. The objective of this paper is to characterize the effects of section size and position within a heavysection casting on the high-cycle fatigue (HCF) properties of ADI by systematic experiments on specimens cut from Y-blocks with three section sizes $(25,50$, and $100 \mathrm{~mm})$. Effects of similar variables on the low-cycle fatigue (LCF) properties will be the topic of the second part of this series ${ }^{(12)}$. Two austempering treatments were conducted to generate the optimum strength and toughness, respectively, and to determine whether ADI's HCF resistance was directly related to the tensile strength or toughness. These results will be discussed in terms of graphite nodule morphology and matrix structures. 


\section{Experimental Procedures}

Y-blocks with three section sizes, 25,50 , and $100 \mathrm{~mm}$ in leg thickness (see Fig. 1), were cast in a high-production commercial foundry. These ductile iron castings were cast in sand molds with the chemical compositions given in Table 1. These castings were classified as small $(\mathrm{S})$, middle (M), and large (L) for the section size of 25 , 50 , and $100 \mathrm{~mm}$, respectively. Each Y-block leg with riser removed was sectioned into rectangular bars in a manner shown in Fig. 2. Three, six, and twelve rectangular bars produced for each S, M, and L casting, respectively, were marked as shown in Fig. 2 to identify their positions within the castings. Positions SB, MB, and LB were selected to investigate the effect of cast section size on fatigue properties of ADI. LB and LT were selected to study the sensitivity of ADI fatigue properties to position within a heavy-section casting simply because LT is ex-

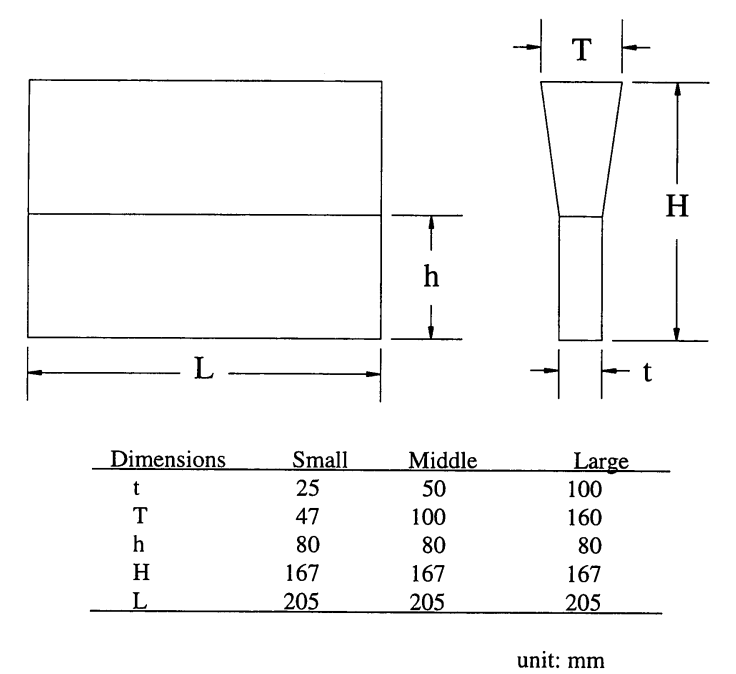

Fig. 1 Dimensions of Y-blocks in three different section sizes.

Table 1 Chemical composition of ADIs tested. (mass\%)

\begin{tabular}{ccccccccccc}
\hline \hline $\begin{array}{c}\mathrm{C} \\
(\%)\end{array}$ & $\begin{array}{c}\mathrm{Si} \\
(\%)\end{array}$ & $\begin{array}{c}\mathrm{Mn} \\
(\%)\end{array}$ & $\begin{array}{c}\mathrm{P} \\
(\%)\end{array}$ & $\begin{array}{c}\mathrm{S} \\
(\%)\end{array}$ & $\begin{array}{c}\mathrm{Mg} \\
(\%)\end{array}$ & $\begin{array}{c}\mathrm{Cu} \\
(\%)\end{array}$ & $\begin{array}{c}\mathrm{Ni} \\
(\%)\end{array}$ & $\begin{array}{c}\mathrm{Mo} \\
(\%)\end{array}$ & $\begin{array}{c}\mathrm{Fe} \\
(\%)\end{array}$ \\
\hline 3.5 & 2.2 & 0.21 & 0.025 & 0.0090 .032 & 0.42 & 0.46 & 0.16 \\
$\sim 3.56$ & $\sim 2.34$ & $\sim 0.22$ & $\sim 0.027$ & $\sim 0.048$ & $\sim 0.44$ & $\sim 0.48$ & $\sim 0.18$ \\
\hline \hline
\end{tabular}

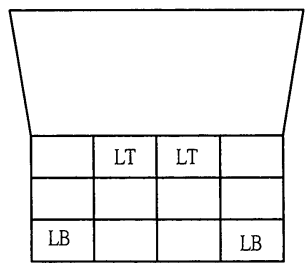

Large cast

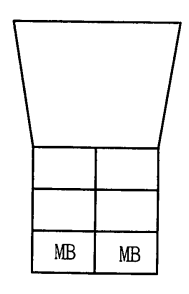

Middle cast

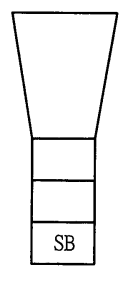

Small cast
Fig. 2 Positions (with marked labels) selected for high-cycle fatigue testing in three different Y-block section sizes. pected to be the last to freeze volume and have the most deteriorated graphite structure. Tensile, HCF, and impact specimens with dimensions shown in Fig. 3 were machined from these rectangular bars. Tensile and HCF specimens were initially machined to the stage with excess materials of $2 \mathrm{~mm}$ in diameter remained, followed by heat treatment. The final stages of machining, grinding, and polishing were conducted after heat treatment. The gage sections of the tensile and HCF specimens were polished in the axial direction to a 800 -grit finish to remove undesirable horizontal machining marks.

Different matrix structures in ADI and the associated mechanical properties can be obtained by choosing proper combinations of heat treatment variables, including austenitizing temperature and time and austempering temperature and time ${ }^{(13)}$. Two different austempering treatments were applied to given ductile irons so as to investigate the effect of ausferritic structure on the HCF strength of ADI. One of these austempering treatments was selected to generate the optimum strength (with a maximum value of ultimate tensile strength) and the other to generate the optimum toughness (with a maximum value of impact toughness). Details of the procedures for selecting these two austempering conditions for the ductile irons with similar chemical compositions are given elsewhere ${ }^{(14)}$. Test specimens were first austenitized in salt bath at $1173 \mathrm{~K}$ for $1.5 \mathrm{~h}$ after which they were quenched in a salt bath either at $573 \mathrm{~K}, 3 \mathrm{~h}$ for optimum strength or at $633 \mathrm{~K}, 2 \mathrm{~h}$ for optimum toughness; they were then cooled in forced air.

HCF tests were conducted using a rotary bending fa-

(a)

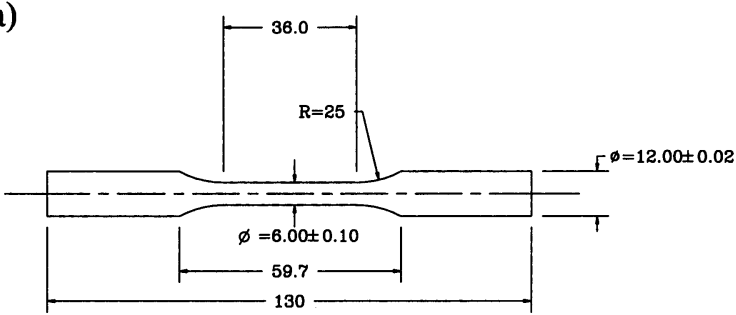

(b)

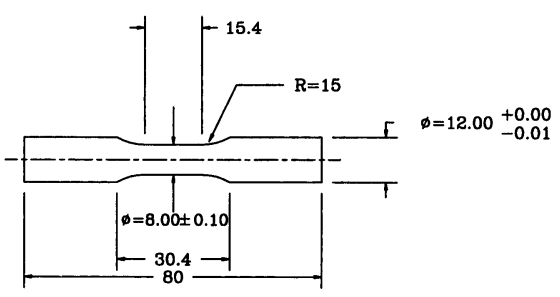

(c)

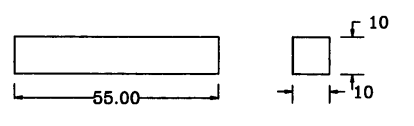

Dimensions: $\mathrm{mm}$

Fig. 3 Geometries of specimens: (a) tensile test specimen, (b) high-cycle fatigue specimen, and (c) impact specimen. 
tigue testing machine. Testing was performed at a frequency of $40 \mathrm{~Hz}(2400 \mathrm{rpm})$ until specimen failure or $10^{7}$ cycles at which specimen was considered to be a runout. $\mathrm{S}-\mathrm{N}$ curves were established in both austempered conditions for each group of specimens cut from the same position. Eight to ten specimens of each group were tested at several stress levels to obtain reliable S-N curves and fatigue limits. Fatigue limit was estimated as the stress level midway between the lowest stress at which failure was observed and the highest stress at which no failure was observed.

Metallographic and X-ray samples cut from each selected position were prepared for microstructural observation. An image analyzing system was applied to evaluate the graphite structure such as nodule counts, nodule diameter, and nodularity. These data were measured on 25 fields in each specimen and averaged. A specific electrolytic etching technique ${ }^{(15)}$ was adopted for etching the specimens of ADIs to observe the ausferritic structure in matrix. Both optical (OM) and scanning electron microscopes (SEM) were used to examine these samples. X-ray diffraction was conducted to determine the volume fraction of retained austenite in ADI matrix. The samples were analyzed over an angular range of $2 \theta 40-45^{\circ}$ using a copper target and nickel filter at a scan speed of $0.05^{\circ} \mathrm{s}^{-1}$.

\section{Results and Discussion}

\section{Microstructural observations}

Figure 4 shows the typical graphite structures obtained from four positions in three section sizes. The data of nodule counts, nodule diameter, and nodularity for each selected location are given in Table 2 . The quality of the overall graphite morphology for these positions can be ranked in the following order: $\mathrm{SB}>\mathrm{MB}>\mathrm{LB}>\mathrm{LT}$. Increasing the leg thickness of a Y-block casting decreases the nodule counts and nodularity of irons but increases the nodule size. The microstructure of the as-cast ductile irons in the four specific positions all consisted of a bull's eye structure in the pearlitic matrix. Although the lamellae spacing is slightly greater in the heavy-section casting, this minor difference in the pearlitic matrix among the four positions can be removed through proper austempering heat treatment. Representative micrographs of the microstructures formed by austempering at 573 and 633 $\mathrm{K}$ are shown in Fig. 5 for positions SB and LT. The
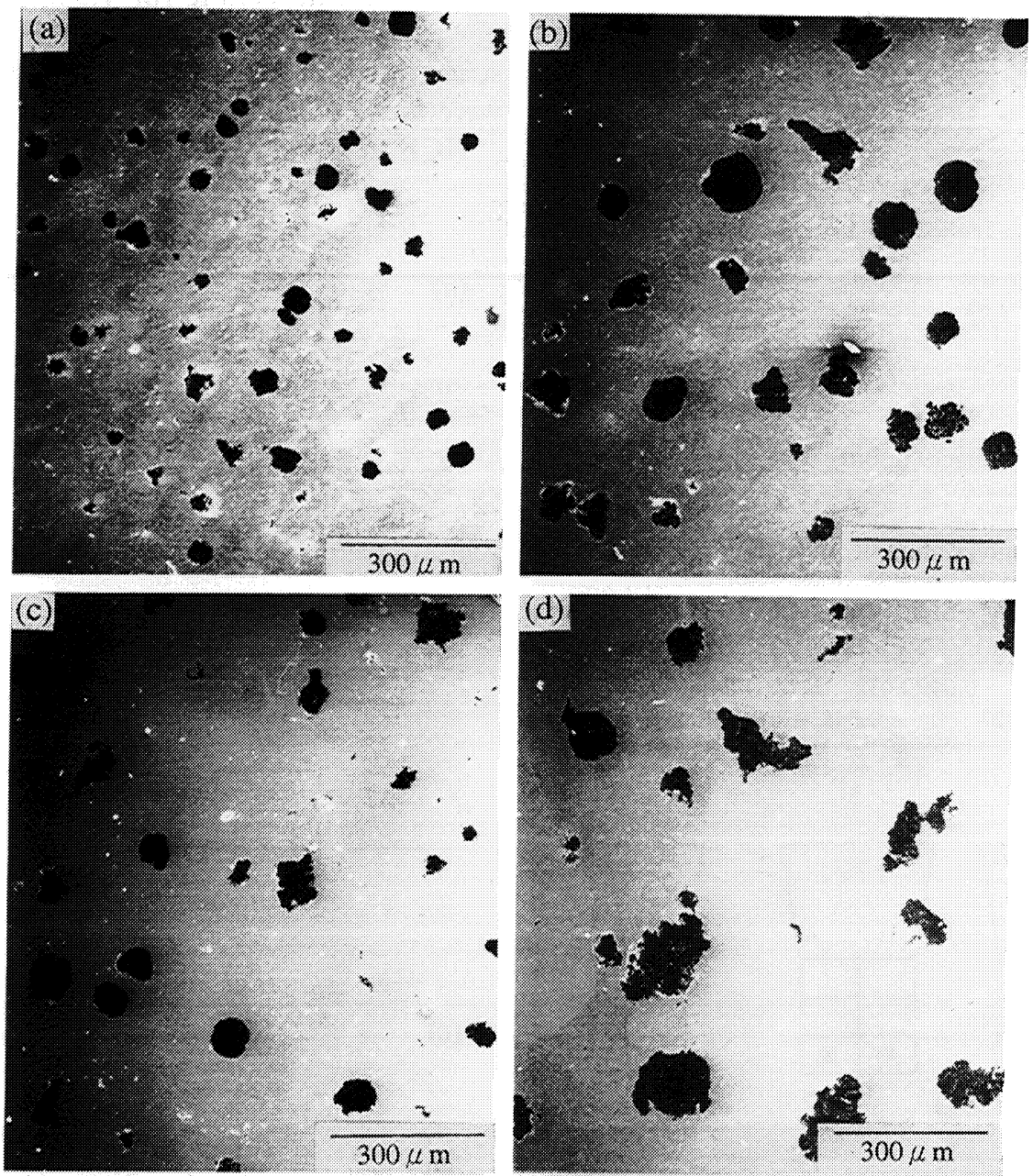

Fig. 4 Typical graphite microstructures in different section sizes and positions: (a) SB, (b) MB, (c) LB, and (d) LT. 
Table 2 Nodule data of ADIs tested.

\begin{tabular}{cccc}
\hline \hline Position & Nodules $/ \mathrm{mm}^{2}$ & $\begin{array}{c}\text { Nodule Diameter } \\
(\mu \mathrm{m})\end{array}$ & $\begin{array}{c}\text { Nodularity } \\
(\%)\end{array}$ \\
\hline SB & $\sim 90$ & 34 & $\sim 90$ \\
MB & $\sim 45$ & 49 & $\sim 80$ \\
LB & $\sim 40$ & 56 & $\sim 75$ \\
LT & $\sim 35$ & 65 & $\sim 70$ \\
\hline \hline
\end{tabular}

round dark areas presented in these higher magnification micrographs are graphite nodules. In general, variation in the morphology of ausferrite in the matrix was minor for the four specific positions given a austempering condition. At a lower austempering temperature $(573 \mathrm{~K})$ the ferrite laths are finer and closer, and accompanied by fewer amounts of retained austenite exhibited on the matrix, as shown in Figs. 5(a) and (c). At a higher austempering temperature $(633 \mathrm{~K})$, the ferrite laths become coarser and shorter and a high fraction of austenite islands are uniformly distributed in the matrix, as shown in Figs. 5(b) and (d). In fact, the major difference in the matrix structures for these positions is the existence of a greater fraction of microshrinkage pores in position LT as compared to positions SB, MB, and LB. Figure 6 shows the typical microshrinkage pores found in LT specimens cut from the top, hot spot of heavy-section ADIs. It is difficult to homogenize irons, which are with apparent microshrinkage pores in the matrix, by heat treatment.

\section{Mechanical properties of ADIs tested}

Table 3 lists the mechanical properties in as-cast and two given austempered conditions for specimens from four locations in three section sizes. For a given position, the values of ultimate tensile strength, yield strength, and hardness obtained at $573 \mathrm{~K}$ are considerably greater than those obtained at $633 \mathrm{~K}$ while the elongation and toughness take the reverse trend. Similar results have been widely reported for other $\mathrm{ADIs}^{(1)}$. Such differences in the mechanical properties for a given position can be attributed to the variation of ausferritic structure in matrix. The higher toughness and ductility values obtained at $633 \mathrm{~K}$ result from the larger amounts of retained austenite exhibited on the matrix of ADI, as illustrated by the micrographs in Fig. 5. The results of X-ray diffraction analysis (Table 4) show the volume fraction of retained austenite for ADIs austempered at $633 \mathrm{~K}$ is remarkably larger than that for those austempered at $573 \mathrm{~K}$, i.e. $12-21 \%$ versus $3-5 \%$.
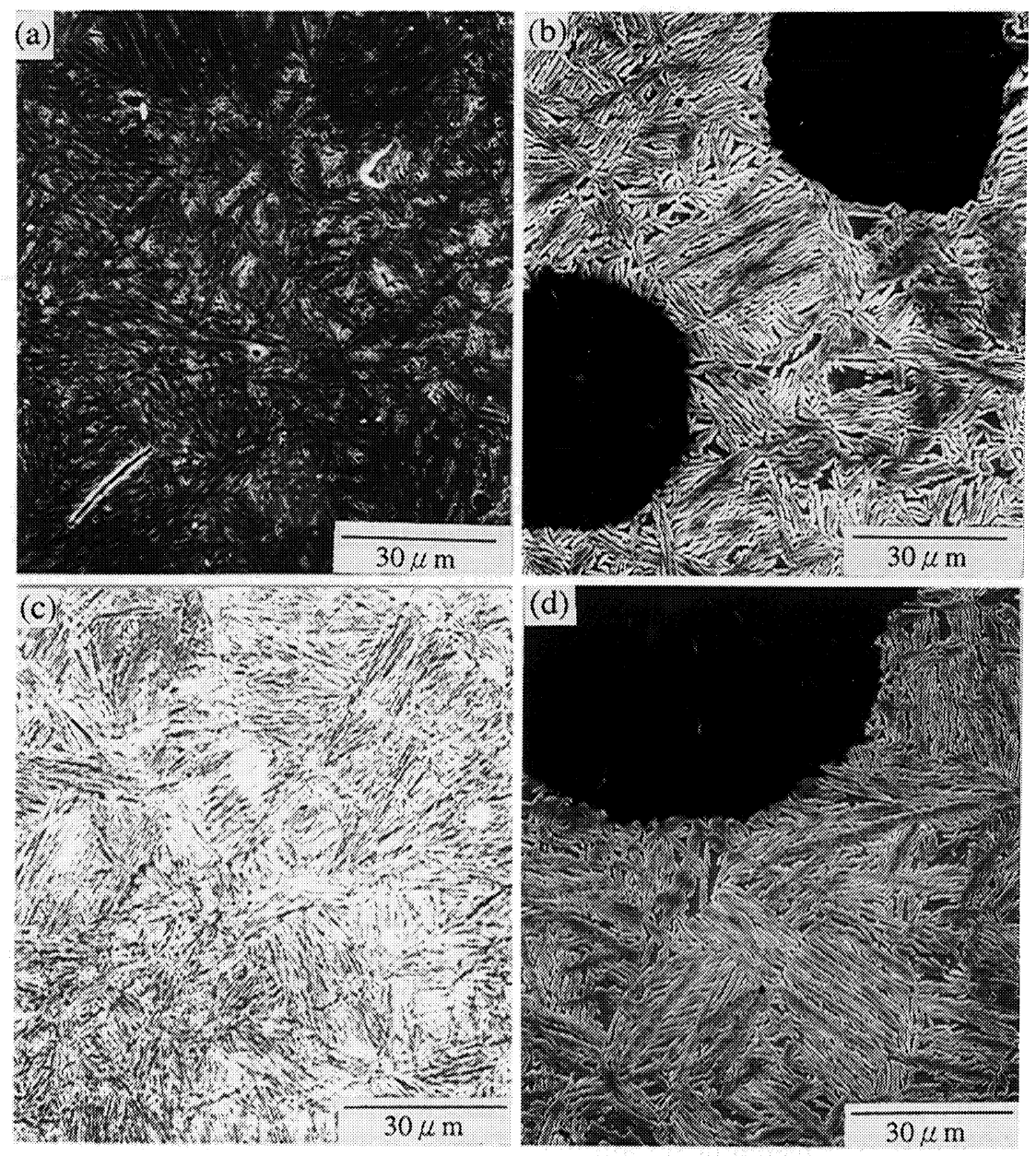

Fig. 5 Typical ADI microstructures in different section sizes and austempered conditions: (a) SB, $573 \mathrm{~K}, 3 \mathrm{~h}$, (b) SB, $633 \mathrm{~K}$, $2 \mathrm{~h}$, (c) LT, $573 \mathrm{~K}, 3 \mathrm{~h}$, and (d) LT, $633 \mathrm{~K}, 2 \mathrm{~h}$. (Round dark areas in (b) and (d) are graphite nodules.) 
Table 3 Mechanical properties of as-cast and austempered ductile irons tested.

\begin{tabular}{|c|c|c|c|c|c|c|c|}
\hline $\begin{array}{l}\text { Austempering } \\
\text { condition }\end{array}$ & Position & $\begin{array}{c}\text { Tensile } \\
\text { strength } \\
(\mathrm{MPa})\end{array}$ & $\begin{array}{l}\text { Yield } \\
\text { strength } \\
\text { (MPa) }\end{array}$ & $\begin{array}{l}\text { Modulus of } \\
\text { elasticity } \\
\text { (MPa) }\end{array}$ & $\begin{array}{c}\text { Elongation } \\
(\%)\end{array}$ & $\begin{array}{l}\text { Impact } \\
\text { toughness } \\
(\mathrm{J})\end{array}$ & $\begin{array}{l}\text { Hardness } \\
\text { (HRc) }\end{array}$ \\
\hline \multirow{4}{*}{ as-cast } & $\mathrm{SB}$ & 772 & 448 & 159762 & 7.09 & 36.5 & 22.9 \\
\hline & MB & 695 & 413 & 156831 & 5.03 & 22.8 & 18.6 \\
\hline & LB & 740 & 424 & 164106 & 3.75 & 14.7 & 21.3 \\
\hline & $\mathrm{LT}$ & 753 & 431 & 153009 & 5.17 & 10.1 & 19.4 \\
\hline \multirow{3}{*}{$573 \mathrm{~K}, 3 \mathrm{~h}$} & MB & 1246 & 975 & 157003 & 0.13 & 57.0 & 47.9 \\
\hline & LB & 1147 & 1117 & 167003 & 0.10 & 50.4 & 48.7 \\
\hline & $\mathrm{LT}$ & 1005 & 962 & 139306 & 0.04 & 26.7 & 50.0 \\
\hline \multirow{4}{*}{$633 \mathrm{~K}, 2 \mathrm{~h}$} & SB & 1036 & 901 & 166726 & 1.64 & 143.0 & 38.4 \\
\hline & MB & 1011 & 898 & 163712 & 0.98 & 98.6 & 38.7 \\
\hline & LB & 1022 & 900 & 172660 & 1.45 & 92.3 & 37.9 \\
\hline & LT & 1025 & 910 & 152527 & 1.28 & 49.3 & 39.3 \\
\hline
\end{tabular}
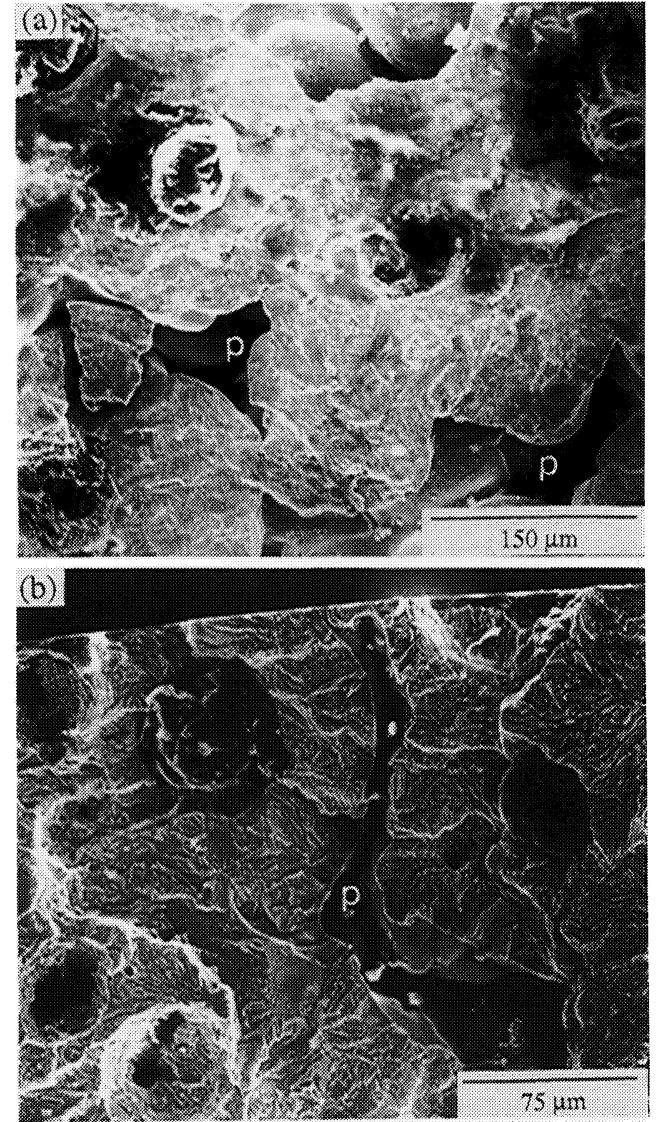

Fig. 6 SEM micrographs of typical microshrinkage pores in heavysection ADI (position LT): (a) in general matrix and (b) as fracture origin. ( $\mathrm{p}$ : microshrinkage pore)

For ADIs austempered at $633 \mathrm{~K}, 2 \mathrm{~h}$, the tensile and yield strength, hardness, and elongation did not show a significant variation with section size and position. However, the impact toughness values did show a great difference and take the following order: $\mathrm{SB}>\mathrm{MB}>\mathrm{LB}>$ LT. As the variation of ausferritic structure and content of retained austenite in the matrix is insignificant among these four locations in the three section sizes, the decrease in toughness with increasing section size and
Table 4 Retained austenite content and fatigue limit of ADIs tested in different section sizes and positions.

\begin{tabular}{cccc}
\hline \hline $\begin{array}{c}\text { Austempering } \\
\text { condition }\end{array}$ & Position & $\begin{array}{c}\text { Volume fraction } \\
\text { of retained } \\
\text { austenite (\%) }\end{array}$ & $\begin{array}{c}\text { Fatigue limit } \\
\text { (MPa) }\end{array}$ \\
\hline \multirow{5}{*}{$573 \mathrm{~K}, 3 \mathrm{~h}$} & SB & 5.01 & $\sim 350$ \\
& MB & 4.58 & $\sim 312$ \\
& LB & 4.20 & $\sim 218$ \\
& LT & 3.09 & $\sim 195$ \\
\hline \multirow{5}{*}{$633 \mathrm{~K}, 2 \mathrm{~h}$} & SB & 20.89 & $\sim 410$ \\
& MB & 12.08 & $\sim 340$ \\
& LB & 17.37 & $\sim 312$ \\
& LT & 19.77 & $\sim 244$ \\
\hline \hline
\end{tabular}

distance from the sand mold is mostly attributed to the slower solidification rate in a thicker casting. Among the four specific positions, LT was expected to have the slowest solidification rate. This expectation was confirmed by the fact that position LT indeed exhibited the lowest nodule counts, lowest nodularity, largest nodule size, and presence of more microshrinkage pores. In addition, lower nodule counts and larger nodule sizes would enlarge the eutectic cell size and increase the severity of alloy segregation. These effects together make position LT have the lowest toughness. In particular, the existence of a higher fraction of microshrinkage pores might play a more important role in reducing the toughness value for position LT. This can be seen by the fact that both positions LB and LT have close values in nodule counts (35-40 nodules $/ \mathrm{mm}^{2}$ ) and nodularity (70-75\%) but more microshrinkage pores were found in position LT. This tendency in variation of toughness with section size and position is also true for ADIs austempered at $573 \mathrm{~K}$, $3 \mathrm{~h}$. The tensile strengths for ADIs austempered at $573 \mathrm{~K}$, $3 \mathrm{~h}$, however, did exhibit a certain sensitivity to section size and position and take the following order: $\mathrm{SB}>\mathrm{MB}>\mathrm{LB}>\mathrm{LT}$. This is due to the fact that the ausferritic matrix structure in ADI austempered at $573 \mathrm{~K}$ is more brittle than that austempered at $633 \mathrm{~K}$ such that the sensitivity of tensile strength to graphite structure and 
casting defects is more pronounced at $573 \mathrm{~K}$.

In summary, the degradation of mechanical properties for heavy-section ADI, in particular at the last to freeze volume, is attributed to the slower solidification rate leading to the poor graphite nodule structure, larger eutectic cell size, and existence of a higher fraction of microshrinkage pores. In addition, the tensile strength of ADI is mostly determined by the morphology of ausferrite in the matrix and the fraction of microshrinkage porosity plays an important role in influencing the toughness.

\section{Effect of austempering treatment on HCF strength}

Results of the rotary bending fatigue S-N curves for all ADIs selected from four positions in three section sizes are shown in Fig. 7. The best-fit lines were used in all subsequent comparisons of HCF properties. The estimated fatigue limits are given in Table 4. Estimated fatigue limits for ADIs austempered at $573 \mathrm{~K}$ range from 195 to $350 \mathrm{MPa}$. At a higher austempered temperature $(633 \mathrm{~K})$, the estimated fatigue limits are of the values from 244 to $410 \mathrm{MPa}$. In general, for a given section size and position, the fatigue limits take the following order: austempered at $633 \mathrm{~K}>$ austempered at $573 \mathrm{~K}$ (Table 4). In other words, maximum HCF strength of a ductile iron was achieved with austempering treatment which generated optimum toughness and greater amounts of retained austenite. Therefore, the fatigue limit in ADI is not proportional to tensile strength or hardness, as with most steels. Similar results are also reported in the published literature $^{(1)(14)(16)-(20)}$.

Greater amounts of retained austenite can create more barriers for fatigue crack growth and extend life. This might be related to the plasticity-induced martensitic transformation of unstable retained austenite during HCF testing. The HCF tests were conducted under rotary bending conditions where the material near the outersurface of specimen was subjected to the maximum applied stress amplitude while the material at neutral axis of specimen was not stressed at all. Therefore, the fatigue cracks in HCF usually started at or near the surfaces of specimens and the plasticity-induced martensitic transformation of unstable retained austenite would likely to occur locally at the highly stressed area ahead of the fatigue crack tip. Such transformation occurring in the plastic zone ahead of the crack would relax the stress concentration at the crack tip ${ }^{(18)}$. The accompanying volume change due to martensitic transformation also urged plastically induced crack closure to occur, reducing the fatigue crack growth rate and increasing fracture toughness ${ }^{(18)}$. A study made by Tanaka and Ishii ${ }^{(21)}$ also confirmed that a beneficial effect to reduce the fatigue crack growth rate in ADI could be caused by phase transformation from unreacted, unstable austenite to martensite at the area ahead of the fatigue crack tip.

As ADIs austempered at $633 \mathrm{~K}, 2 \mathrm{~h}$ have much more blocky retained austenite (Fig. 5), presumably, a greater proportion of unreacted, unstable austenite in low carbon concentration may accompany these ADIs in comparison to ADIs austempered at $573 \mathrm{~K}, 3 \mathrm{~h}$. As reported by Grech and Young ${ }^{(18)}$, these austenite blocks residing among ausferrite subgrains and cell boundaries are relatively non-uniform in soluted carbon content. Therefore, such unreacted, unstable blocky austenite with low carbon content soluted in the center is more likely to trans-
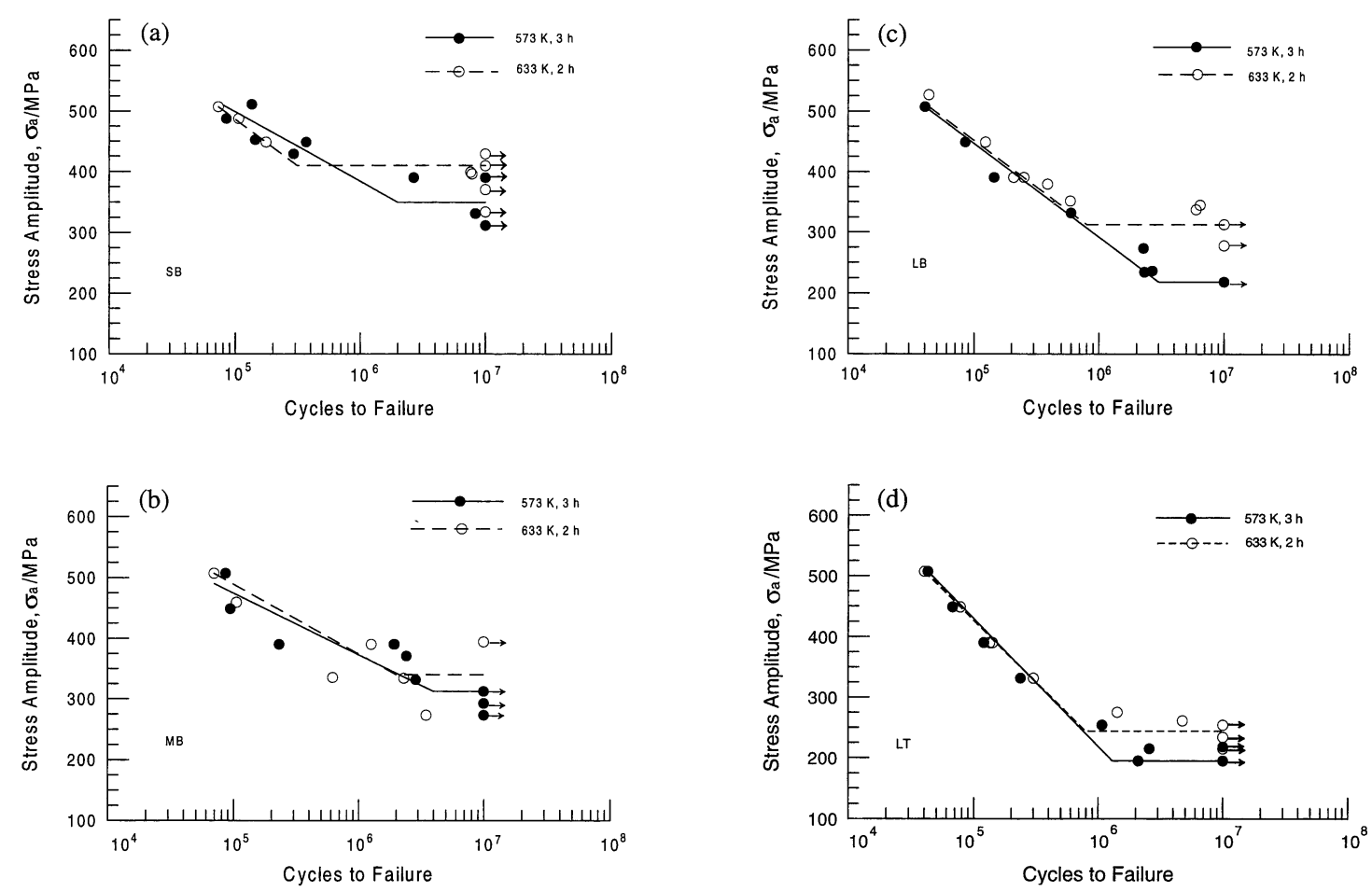

Fig. 7 S-N curves in different section sizes and positions: (a) SB, (b) MB, (c) LB, and (d) LT. (Arrows designate runout (c) tests.) 
form to martensite under plastic deformation than carbon-enriched stable austenite ${ }^{(18)}$. It has also been reported by Aranzabal et al. ${ }^{(22)}$ that a larger fraction of retained austenite would undergo martensitic transformation under plastic deformation in ADIs austempered at higher temperatures with greater amounts of retained austenite. Therefore, more plasticity-induced martensitic transformation of unstable retained austenite may occur ahead of the fatigue crack tip in ADIs austempered at $633 \mathrm{~K}$ during HCF testing and lead to a better HCF performance in comparison to ADIs austempered at $573 \mathrm{~K}$ for a given section size and position. Apparently, such crack closure effects make a higher austempering temperature $(633 \mathrm{~K})$, which generated greater amounts of retained austenite, desirable for both enhanced toughness and improved fatigue limit. Note that for the stable retained austenite, it would deform plastically with the formation of twins instead of transformation under external loads ${ }^{(22)(23)}$. Figure 8 shows a SEM micrograph taken near the fracture surface of a fatigued specimen austempered at $633 \mathrm{~K}, 2 \mathrm{~h}$. The lath-like martensite generated by plasticity-induced transformation of unstable austenite may be visible within the blocky retained austenite in Fig. 8. It should be noted that in Fig. 8 the dissipation of austenite stringer within the colony of ferrite is also visible where may also exists transformed martensite to a certain extent.

\section{Effect of section size on HCF strength}

Comparing the S-N curves among positions SB, MB, and $\mathrm{LB}$ in each austempered condition can provide an access to understand the effect of section size on the HCF properties of ADI. Figure 9 shows the comparison of HCF strength among these positions with two different austempering treatments. As the difference in the fraction of microshrinkage porosity among these three positions was minor from the microstructural observations, the variation of fatigue limit might be primarily attributed to the difference in graphite nodule structure and associated effects. In both austempered conditions, SB with the greatest nodule counts, smallest nodule size, and best

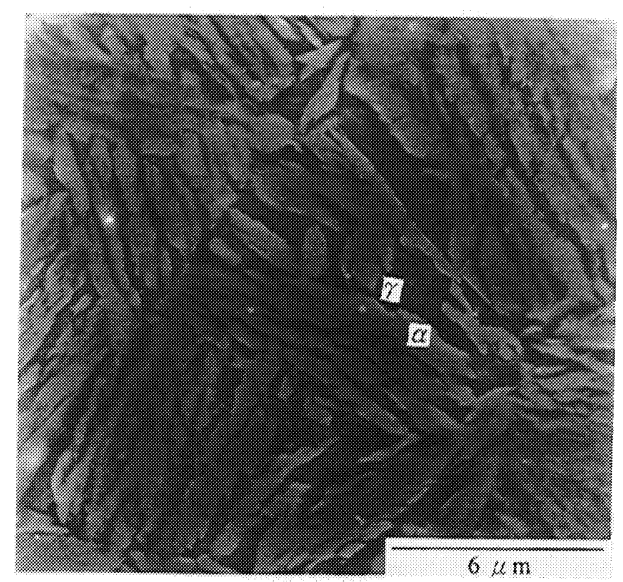

Fig. 8 SEM micrograph taken near the fracture surface of a fatigued specimen (SB, $633 \mathrm{~K}, 2 \mathrm{~h}$ ). ( $\alpha$ : ferrite, $\gamma$ : austenite)
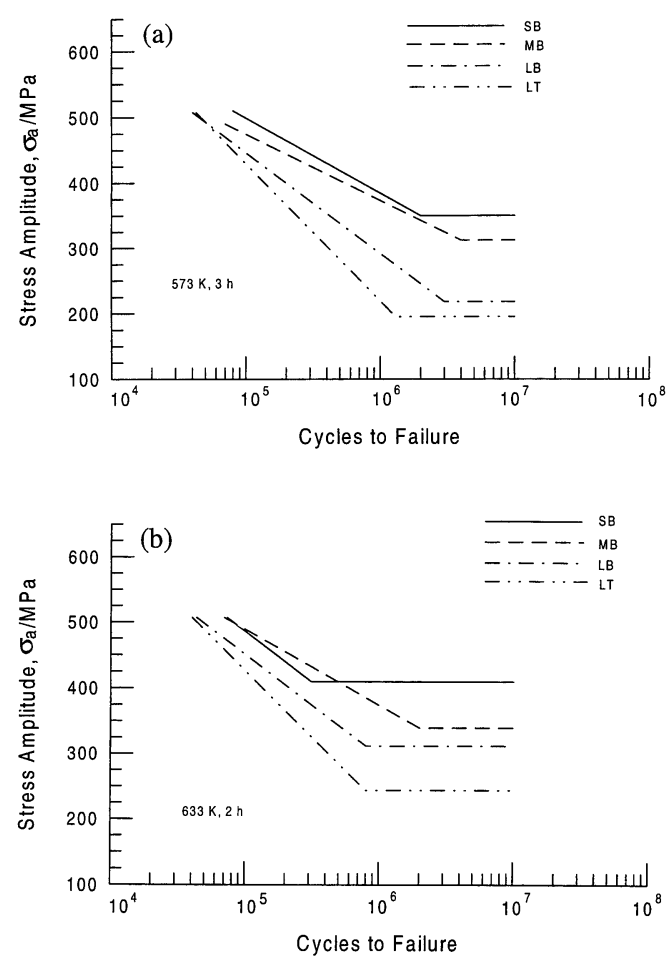

Fig. 9 Comparison of S-N curves in different section sizes and positions at austempered conditions with (a) optimum strength and (b) optimum toughness.

nodularity tended to have a best HCF performance including greater fatigue limits and longer cycles to failure at stress levels above fatigue limits. Although all of the three positions were selected from the bottom, nearest the vertical sand mold surface, the nodule structure became worse as casting section size was increased from $25 \mathrm{~mm}$ (SB) to $100 \mathrm{~mm}$ (LB). The slower solidification rate occurring in the heavy-section ADI made LB have the lower nodule counts, larger nodule size, poorer nodularity, and larger eutectic cell size as compared to SB and MB. Therefore, position LB has the lowest fatigue strength among the three bottom positions selected.

In general, the HCF resistance of ADI is reduced when the overall nodule structure degraded. The graphite nodule can be considered as an internal defect because its strength and hardness values are significantly lower than those of matrix. If the concept of the fatigue notch factor is applied to the graphite nodule, a lower fatigue notch factor is expected for a smaller defect due to a smaller stress gradient given a notch geometry, as for most metals. Therefore, ADI with greater nodule counts or a smaller nodule size exhibits a better HCF resistance. Similar trends were also observed in other ductile irons, especially with high matrix hardness ${ }^{(1)(7)}$. In addition, ADI with an inferior nodularity has more graphite nodules of nonspheroidal shape and higher stress concentration factors as compared to spheroidal shape. As a result, the HCF strength was reduced for $\mathrm{MB}$ and $\mathrm{LB}$ due to poor graphite nodule structure as compared to SB.

In addition, the difference in $\mathrm{HCF}$ strength due to section size was enhanced when the austempering tempera- 
ture was decreased (Table 4). As shown in Fig. 10, the percentage of difference in fatigue limit between SB and LB increased from 24 to $38 \%$ as austempering temperature decreased from 633 to $573 \mathrm{~K}$. This is attributed to the more severe notch effect of graphite nodules and other casting defects in a matrix with higher strength and hardness formed at a lower austempering temperature. Strengthening the matrix in ductile irons can intensify the difference in mechanical properties between graphite nodule and matrix. Consequently, it would be of less resistance for the occurrence of decohesion of graphite nodules in a strong matrix than in a more ductile and softer matrix.

\section{Position sensitivity of HCF strength for heavy- section ADI}

The variation of ADI fatigue strength with position within a heavy-section casting can be seen by comparing the S-N curves obtained for positions LB and LT. Note that LB is the position having the fastest solidification rate and LT is expected to be the last to freeze volume in the $100 \mathrm{~mm}$-thickness Y-block after removing the riser. It is seen in Fig. 9 that position LB exhibits more fatigue resistance than LT at both austempered conditions. As indicated in Table 2, the graphite nodule morphology in position LB is slightly better than that in position LT in terms of nodule size, nodule counts, and nodularity. Thus, the significant degradation of fatigue strength in position LT might be primarily attributed to the existence of a greater fraction of microshrinkage porosity. It may be argued that segregation of alloy elements such as Mo and Mn might occur in the tested ADIs at the cell boundary due to the larger eutectic cell size, and somewhat affect the fatigue properties of heavy-section ADI. However, the effect of alloy segregation on the fatigue strength variation between positions LB and LT might be secondary, as the nodule counts, nodule size, and thus the eutectic cell size in these two positions are of minor difference. Thus the microshrinkage pores play the most important role in reducing the fatigue limit for position LT as compared to LB. Note that some of the micro-

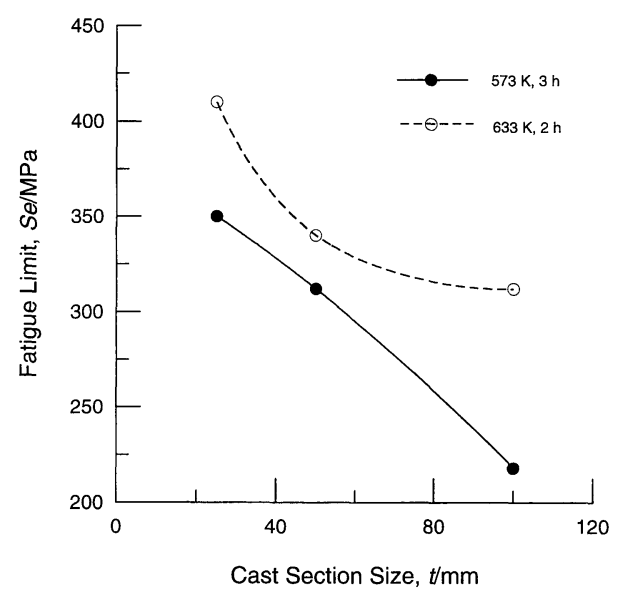

Fig. 10 Relationship between cast section size and fatigue limit of ADI. shrinkage pores were nonspheroidal and even larger than graphite nodules, thus having a greater fatigue notch factor. The existence of these casting defects would reduce the toughness of ADI and in turn the fatigue strength as the ADI fatigue strength depend mainly on the toughness. Therefore, the difference in fatigue limit between positions LB and LT is more pronounced at austempering temperature of $633 \mathrm{~K}$ due to the greater difference in impact toughness value.

SEM observation of fracture surfaces indicated fatigue failures in both HCF and LCF (in the accompanying paper $\left.{ }^{(12)}\right)$ specimens initiated mostly from large graphite nodules, microshrinkage pores, and poorly formed nodules present at or near the surface of the specimen. These casting defects often have a more severe notch effect than spheroidal nodules, resulting in a higher stress concentration to facilitate crack nucleation. Figure 6(b) shows the typical failure origin at a large microshrinkage pore found in a LT specimen. Fracture origins at microshrinkage pores were seldom found in other positions such as $\mathrm{SB}, \mathrm{MB}$, and $\mathrm{LB}$. This provides the possible evidence that microshrinkage porosity indeed plays an important role in reducing the fatigue lifetime for position LT as compared to LB. Details of the observation and discussion on the fatigue crack initiation and growth mechanisms in ADI are given in the accompanying paper ${ }^{(12)}$.

The typical microshrinkage pore frequently found in position LT has been shown by a microfractograph in Fig. 6. Moreover, measurement of the bulk density for material selected from each position under a given austempering condition might provide some clues to reflect the tendency in the volume fraction of microshrinkage porosity among the four specific positions. The bulk density of the sample cut from the gage section of the HCF specimen after fatigue failure was measured using Archimedes' principle. From the group of HCF specimens austempered at $573 \mathrm{~K}$, five broken specimens in each position were selected for density measurement. The average observed values of the bulk density for samples selected from positions SB, MB, LB, and LT are $7.54,7.52,7.40$, and $7.20 \mathrm{Mg} / \mathrm{m}^{3}$, respectively. The lowest density value obtained in position LT might, somewhat, present some possible evidence for the existence of a higher volume fraction of microshrinkage pores in addition to the microstructural observations. However, both microstructural observation and bulk density measurement show the tendency in volume fraction of microshrinkage porosity among the four specific positions in a qualitative manner. Future research is necessary in quantitatively measuring the volume fraction and size of microshrinkage pores by a more precise technique.

As reported in a previous study by Faubert et al. ${ }^{(11)}$, the sensitivity of ADI fatigue strength to position in heavysection castings was quite small. This is different from the results obtained in the present study. The fatigue specimens in the study of Faubert et al. ${ }^{(11)}$ were cut and machined after the austempering treatment of the entire Y-block legs while the specimens in the current work were austempered as individual bars. However, it has 
been reported in another study by Faubert et al. ${ }^{(6)}$ that specimens either from the austempered Y-block leg or individually austempered exhibited similar tendency of position sensitivity on tensile properties (ultimate tensile strength, yield strength, and elongation) for a heavy-section casting. As positions LB and LT in the current study are both located near the outersurfaces of the riser-removed Y-block leg, these two positions were expected to have very close cooling rate during the transition from the austenitizing to the austempering temperature if the entire Y-block leg were austempered. Therefore, ADI specimens from LB and LT positions are expected to show similar trend of position sensitivity on the mechanical and fatigue properties whether they were austempered individually or from the entire austempered Y-block leg. In addition, the fatigue data in the study of Faubert $e t$ $a l .{ }^{(1)}$ were obtained from two groups of specimens broadly defined as those taken from the upper half of the $\mathrm{Y}$ block leg and those taken from the lower half. Therefore, the specimens in each group might come from various locations within each half of the Y-block leg and have different cooling rates during austempering treatment. The superposition of heat treatment effects on microstructure on the existing effects of solidification history might create the greater scatter of data such that no significant position sensitivity of fatigue strength was observed in the study of Faubert et al. ${ }^{(11)}$. However, two specific positions LB and LT representing the volumes with the fastest and slowest solidification rates, respectively, were selected in the current work. This difference in definition of position might explain the different conclusions between the study of Faubert et al. ${ }^{(11)}$ and current work regarding the sensitivity of ADI fatigue limit to position within a heavy-section casting.

\section{Empirical equation of fatigue limit prediction for ADI}

It was suggested by Tanaka et al. ${ }^{(10)}$ that the fatigue limits of several ductile irons including ADI depended mainly on the graphite nodule size. An empirical equation between fatigue limit and graphite nodule size was then introduced for $\mathrm{ADI}^{(10)}$. Similar concept was applied to the current study to generate the relationship between fatigue limit and nodule size for ADIs tested, as shown in Fig. 11. It is seen in Fig. 11 that given a austempering treatment, the fatigue limit decreased linearly with an increase in mean nodule diameter on logarithmic scales. The correlation coefficients of the fitting curves are $r^{2}=0.91$ and 0.84 for austempering temperatures of 633 and $573 \mathrm{~K}$, respectively. As shown in Fig. 11, given a mean nodule diameter, the fatigue limit of ADI austempered at $633 \mathrm{~K}$ is distinctly greater than that austempered at $573 \mathrm{~K}$. Therefore, no unique relationship between fatigue limit and mean nodule size for given ADIs with different austempering treatments can be obtained. Similar tendency can be seen in the study of Tanaka et al. ${ }^{(10)}$ in which the coefficient of correlation for the empirical equation between fatigue limit and mean nodule diameter was $r^{2}=0.83$ by fitting together all of the data of ADIs

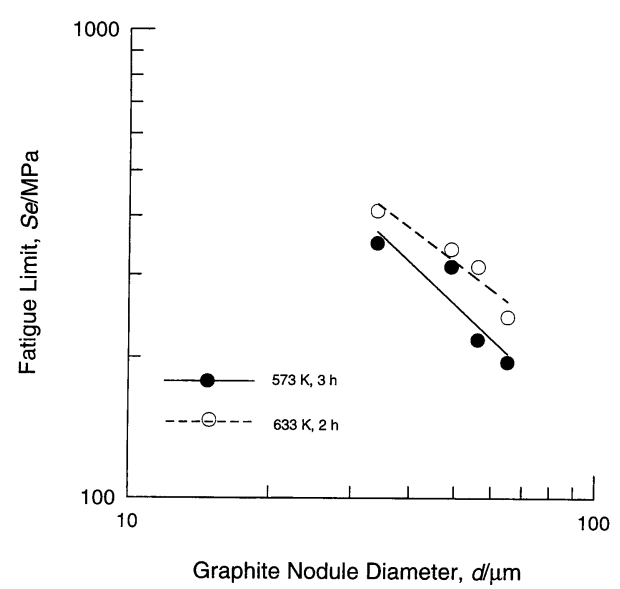

Fig. 11 Influence of graphite nodule diameter on the fatigue limit of ADI.

from three different austempering temperatures. This correlation coefficient is much lower than those $\left(r^{2}=0.94 \sim 0.98\right)$ obtained for other grades of ductile irons reported in the same study by Tanaka et al. ${ }^{(10)}$. Therefore, ADI's fatigue limit might not be evaluated in the same way as other ductile irons simply using the nodule size as the only dominating parameter.

As described above, the degree of sensitivity of ADI fatigue limit to the nodule size is different as the austempering temperature changes. In order to find a universal equation for predicting fatigue limits of ADIs obtained from different austempering treatments, other factors needed to be considered in addition to the graphite nodule size. Tanaka et al. ${ }^{(10)}$ suggested using Vickers hardness value of the matrix to relate to ADI fatigue limit. However, as mentioned above and in other previous studies ${ }^{(1)(14)(16)-(20) \text {, }}$ given a graphite nodule morphology (or section size and position), ADI with greater toughness possessed more HCF resistance and the fatigue limit was not dependent on either tensile strength or hardness. Therefore, it might be more appropriate to use toughness value instead of hardness to correlate with ADI fatigue limit. Therefore, the impact toughness value is proposed in the present study to combine with the mean nodule diameter to correlate with the fatigue limits of ADIs tested. Figure 12 shows the relationship between fatigue limit and mean nodule diameter together with impact toughness value. The best-fit curve for data from four positions in three section sizes, and two austempering treatments given in this study can be expressed as follows:

$$
S_{\mathrm{e}}=371.54 I^{0.31} d^{-0.40} \quad\left(r^{2}=0.91\right)
$$

where $S_{\mathrm{e}}$ is the fatigue limit (MPa), $I$ is the impact toughness $(\mathrm{J})$, and $d$ is the mean nodule diameter $(\mu \mathrm{m})$. This equation indicates that ADI fatigue limit increases with increasing toughness and decreasing nodule size.

As shown in Fig. 12 the fatigue limit data obtained from various section sizes and positions and austempering temperatures can be well related to the impact toughness and nodule size together by eq. (1). This implies that toughness and nodule size are the two major factors controlling the fatigue limit of ADI. As explained by Tanaka 


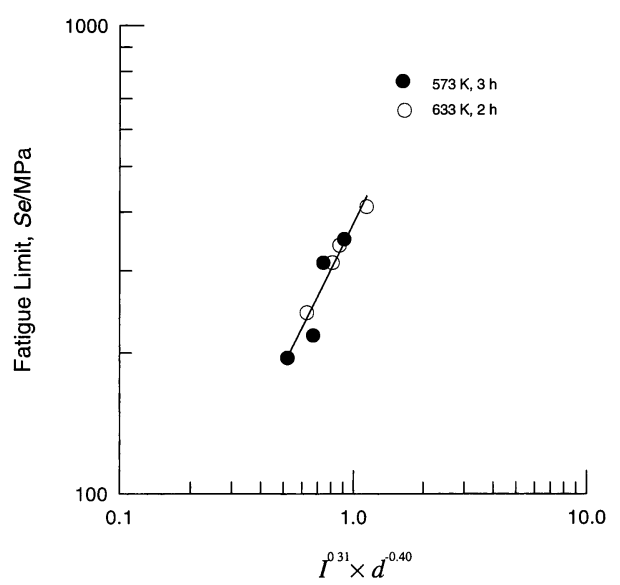

Fig. 12 Relationship of ADI fatigue limit with impact toughness and graphite nodule diameter. (Units for $I$ and $d$ are $\mathrm{J}$ and $\mu \mathrm{m}$, respecitively.)

et al. ${ }^{(10)}$, it would be easier to initiate a fatigue crack around a larger graphite nodule due to a larger volume of high stress from notch effect. In addition, the larger nodule would also increase the stress intensity factor and the crack growth rate, reducing the fatigue life. As described previously, greater toughness would provide more HCF resistance for ADI. The toughness of ADI is affected by many microstructural factors related to matrix structure. First, the ausferritic structure in matrix of ADI varies with austempering temperature. Moreover, for a given austempering treatment, different cast section sizes and positions would possess matrix structures with various types and amounts of casting defects leading to variation in toughness. The volume with a slower solidification rate in a casting would exhibit a lower toughness value due to poor graphite nodule morphology and the existence of microshrinkage porosity and alloy segregation. Therefore, the impact toughness value is a proper parameter that can directly relate the fatigue limit to the effect of a combination of several microstructural factors in matrix for ADIs from various austempering treatments, cast section sizes and section positions. In this regard, the fatigue limit data obtained for given ADIs from four positions in the three section sizes, and two austempering conditions can be well described by the two parameters, impact toughness value and mean nodule diameter.

However, the degree and extent of individual influence from each microstructural factor on the toughness value and in turn the fatigue strength has not been quantitatively studied. It may not be easy to get a comprehensive, statistical set of data for some microstructural factors. For example, the microshrinkage pores are often more subtle and more difficult to monitor and measure, and may occur (in improper processed material) in a nonuniform way within the casting. In order to clarify this problem, further research is necessary, in particular, using fatigue specimens with the microstructural factors under quantitative control through a perfectly controlled process.

\section{Conclusions}

(1) HCF strength of ADI was decreased with increasing section size due to the slower solidification rate. The reduction in fatigue strength was primarily attributed to the increase in graphite nodule size and eutectic cell size, deterioration in nodule shape, and a greater fraction of microshrinkage porosity.

(2) In a heavy-section ADI, specimens cut from the volume away from the riser showed better fatigue resistance than did those near the riser. This difference was also attributed to the variation of solidification rate with position within the heavy-section casting.

(3) Fatigue limit of ADI is not proportional to its tensile strength or hardness, but is related to its toughness. For a given section size and position, ADI heat treated with greater toughness had a better HCF resistance.

(4) Fatigue limits for given ADIs generated from four positions in three section sizes, and two austempered temperatures could be well correlated with impact toughness value and mean nodule diameter though a two-variable power law equation.

\section{Acknowledgments}

This work was funded by the National Science Council of the Republic of China under Contract No. NSC-852216-E-008-013.

\section{REFERENCES}

(1) Y. Tanaka and H. Kage: Mater. Trans., JIM, 33 (1992), 543.

(2) T. N. Rouns, K. B. Rundman and D. M. Moore: AFS Trans., 92 (1984), 815.

(3) R. B. Gundlach and J. F. Janowak: Met. Prog., 12 (1985), 231.

(4) K. L. Hayrynen, D. J. Moore and K. B. Rundman: AFS Trans., 96 (1988), 619.

(5) K. L. Hayrynen, G. P. Faubert, D. J. Moore and K. B. Rundman: AFS Trans., 97 (1989), 747.

(6) G. P. Faubert, D. J. Moore and K. B. Rundman: AFS Trans., 99 (1991), 551.

(7) M. Sofue, S. Okada and T. Sasaki: AFS Trans., 86 (1978), 173.

(8) K. B. Palmer: Brit. Foundryman, 75II (1982), 201.

(9) H. Mayer and B. Barbezat: Second International Conference on ADI, ASME-Gear Research Institute, U.S.A., (1986), p. 99.

(10) Y. Tanaka, Z. Yang and K. Miyamoto: Mater. Trans., JIM, 36 (1995), 749.

(11) G. P. Faubert, D. J. Moore and K. B. Rundman: AFS Trans., 99 (1991), 563.

(12) C.-K. Lin and C.-S. Fu: Mater. Trans., JIM, 38 (1997), 692.

(13) B. Kovacs: AFS Trans., 99 (1991), 281.

(14) C.-K. Lin, P.-K. Lai and T.-S. Shih: Int. J. Fatigue, 18 (1996), 297.

(15) T. S. Shih, P. Y. Lin, C. H. Chang and C. R. Loper, Jr: AFS Trans., 98 (1990), 609.

(16) K. Jokipii: First International Conference on ADI, American Society for Metals, U.S.A., (1984), p. 135.

(17) S. Yoshino: Second International Conference on ADI, ASMEGear Research Institute, U.S.A., (1986), p. 337.

(18) M. Grech and J. M. Young: AFS Trans., 98 (1990), 345.

(19) K. P. Jen, J. Wu and S. Kim: AFS Trans., 100 (1992), 833.

(20) P. Shanmugan, P. P. Rao, K. R. Ududa and N. Venkataraman: J. Mater. Sci., 29 (1994), 4933.

(21) Y. Tanaka and H. Ishii: Imono, 63 (1991), 699.

(22) J. Aranzabal, I. Gutierrez, J. M. Rodriguez-Ibabe and J. J. Urcola: Mater. Sci. Tech., 8 (1992), 263.

(23) T. Kobayashi and H. Yamamoto: Metal. Trans. A, 19A (1988), 319. 